\title{
Coelogyne magnifica (Orchidaceae), a new species from northern Myanmar
}

\author{
Bin Yang ${ }^{1,2}$, Shi-Shun Zhou ${ }^{1,2}$, Qiang Liu' ${ }^{1,3}$, Kyaw Win Maung ${ }^{4}$, \\ Ren Li', Rui-Chang Quan ${ }^{1,2}$, Yun-Hong Tan ${ }^{1,2}$
}

I Southeast Asia Biodiversity Research Institute, Chinese Academy of Sciences, Yezin, Nay Pyi Taw 05282, Myanmar 2 Centre for Integrative Conservation, Xishuangbanna Tropical Botanical Garden, Chinese Academy of Sciences, Menglun, Mengla, Yunnan 666303, P.R. China 3 Gardening and Horticulture Department, Xishuangbanna Tropical Botanical Garden, Chinese Academy of Sciences, Menglun, Mengla, Yunnan 666303, P.R. China 4 Forest Research Institute, Forest Department, Ministry of Environmental Conservation and Forestry, Yezin, Nay Pyi Taw 05282, Myanmar

Corresponding author: Yun-Hong Tan (tyh@xtbg.org.cn)

Academic editor: V. Droissart | Received 27 July 2017 | Accepted 14 September 2017 | Published 12 October 2017

Citation: Yang B, Zhou S-S, Liu Q, Maung KW, Li R, Quan R-C, Tan Y-H (2017) Coelogyne magnifica (Orchidaceae), a new species from northern Myanmar. PhytoKeys 88: 109-117. https://doi.org/10.3897/phytokeys.88.19861

\begin{abstract}
Coelogyne magnifica (Orchidaceae), a new species from Putao, Kachin State, Myanmar, is described and illustrated. It belongs to Coelogyne section Ocellatae Pfitzer \& Kraenzl. and it is morphologically similar to Coelogyne corymbosa and C. taronensis, but can be distinguished from these species by its larger flowers, lanceolate sepals and petals, a narrowly ovate lip, which has two bright yellow patches surrounded by shiny brownish red and two fimbriate or erose-lacerate lateral keels on the lip. The major differences between these species are outlined and discussed.
\end{abstract}

\section{Keywords}

Kachin state, section Ocellatae, key, plant taxonomy, IUCN, Hponkan Razi

\section{Introduction}

The genus Coelogyne Lindl. (Lindley 1821), which consists of approximately 200 species, is distributed from South India, through tropical Asia and the Malay Archipelago into the Pacific as far east as Fiji, with the main centres being in Borneo, Su-

Copyright Bin Yang et al. This is an open access article distributed under the terms of the Creative Commons Attribution License (CC BY 4.0), which permits unrestricted use, distribution, and reproduction in any medium, provided the original author and source are credited. 
matra and the Himalayas (Gravendeel 2000, Clayton 2002, Gravendeel et al. 2001, 2005, Chen and Clayton 2009, George and George 2011). It belongs to the subfamily Epidendroideae, tribe Coelogyneae, subtribe Coelogyninae (Gravendeel et al. 2005). As currently circumscribed based on molecular phylogenetic evidence, Coelo-

gyne is polyphyletic and composed of species belonging to two unrelated groups. It would thus be questionable whether to adopt a Coelogyne s.s. generic delimitation or a Coelogyne s.l. generic circumscription (Gravendeel 2000, Gravendeel et al. 2001). Although revisions of several sections of Coelogyne have been published in the last decade (Gravendeel and de Vogel 1999, Pelser et al. 2000), a comprehensive infrageneric delimitation combined with descriptions of morphological and molecular characters based on more extensive sampling within Coelogyne is needed (Gravendeel et al. 2000, Sierra et al. 2000).

Historically, the study of Coelogyne in Myanmar dates back to Hooker (1890), who reported three Coelogyne species and added one new species Coelogyne longibractata Hook. f.. Currently, 43 species of Coelogyne have been recorded in Myanmar (Kress et al. 2003), although in a recently published field guide to the orchids of Myanmar, only 33 Coelogyne species are described (Kurzweil and Lwin 2014). The most recently identified new species of Coelogyne was Coelogyne putaoensis X.H. Jin, L.A. Ye \& Schuit. is from north Myanmar (Aung et al. 2017). Since the publication of Kress's checklist (Kress et al. 2003), more than 10 new species and 40 new records of Orchidaceae species have been added to the flora of Myanmar from 2001 to the present (Yang and Tan, unpublished data).

During recent China-Myanmar joint field expeditions to survey plant diversity in north Myanmar in May 2016 and 2017, specimens of Coelogyne were found in Putao, Kachin State. On the basis of a detailed examination of the morphological and anatomical characters of this material and of presumed closely similar species (Clayton 2002, Kress et al. 2003, Chen and Clayton 2009, George and George 2011, Subedi 2011, Yonzone 2012a, 2012b, Li and Dao 2014, Gogoi et al. 2015, Aung et al. 2017), the conclusion was made that the specimens collected in Myanmar belong to a species new to science, which is herein described and illustrated.

\section{Material and methods}

Measurements and morphological character assessments of the putative new Coelogyne species were performed and described using specimens and fresh material observed in the field. These data were compared with those for the morphologically similar species C. corymbosa Lindl. and C. taronensis Hand.-Mazz. based on the descriptions of dried herbarium specimens deposited at Xishuangbanna Tropical Botanical Garden herbarium (HITBC), field notes (for C. corymbosa which has also been collected from north Myanmar) and literature descriptions (Chen and Clayton 2009, Subedi 2011, Li and Dao 2014). Protologues and images of type specimens were obtained from Tropicos (http://www.tropicos.org), JSTOR Global Plants (http://plants.jstor.org) and the International Plant Names Index (http://www.ipni.org). 


\section{Taxonomic treatment}

\section{Coelogyne magnifica Y.H. Tan, S.S. Zhou \& B. Yang, sp. nov.} urn:Isid:ipni.org:names:60475278-2

Figures 1, 2

Diagnosis. Coelogyne magnifica is similar to C. corymbosa and C. taronensis, but can be distinguished from these two species by its larger flowers (tepals $4.0-4.9 \mathrm{~cm}$ long), broadly lanceolate sepals and petals, narrowly ovate lip, which has two bright yellow patches surrounded by shiny brownish red and two fimbriate or erose-lacerate keels on the lip.

Type. MYANMAR. Kachin State: Putao, Hponkan Razi Wildlife Sanctuary, 96 58'56.45"E, 27³6'32.42"N, alt. 2450 m, 11 May 2017, Myanmar Exped. 2046 (holotype, HITBC).

Description. Epiphytic or lithophytic herb, $11-15 \mathrm{~cm}$ tall. Rhizome stout, 3-4 mm in diameter, covered by brown, scaly sheaths. Pseudobulbs clustered, developing serially, less than $1 \mathrm{~cm}$ apart from each other, ovoid or oblong-ovoid, strongly wrinkled when dried, 3-3.5 $\times 1.1-1.7 \mathrm{~cm}$, covered with brown sheaths at the base, sheaths narrow triangular ovate, $1.5-4.5 \times 0.7-1.5 \mathrm{~cm}$ long; bifoliate at apex. Leaf blade obovate-oblong or narrowly ovate, coriaceous, $8-11.2 \times 1.8-2.6 \mathrm{~cm}$, with $6-7$ veins, acute; petiole grooved, $0.4-0.8 \mathrm{~cm}$ long. Inflorescence proteranthous to synanthous, peduncle arching, 5-6 cm long, embraced by sheaths below middle, rachis $1.5-2 \mathrm{~cm}$ long; raceme 2- to 3-flowered (simultaneously opening); floral bracts oblong-lanceolate, 1.9-2.1 $\times$ $0.4-0.5 \mathrm{~cm}$, acute, caducous. Flowers fleshy, white, lip adaxially on mid-lobe with two bright yellow patches surrounded by shiny brownish red and connected to front part of each of the side lobes, keels consisting of two parallel crests with white fimbriate prominence. Pedicel and ovary ca. $1.8-2.5 \mathrm{~cm}$ long, glabrous. Dorsal sepal lanceolate, $4.0-6.0 \times 1.0-1.3 \mathrm{~cm}$, with 7-9 veins, acute or shortly acuminate; lateral sepals similar to dorsal sepal, somewhat narrower than dorsal sepal, $5.0-5.5 \times 0.9-1.5 \mathrm{~cm}$, with 5-7 veins, acute or shortly acuminate; petals lanceolate, $4.0-5.3 \times 0.6-1.0 \mathrm{~cm}$, acute or shortly acuminate; lip narrowly ovate when flattened, 3.8-4.9 × 1.7-2.2 cm, 3-lobed; lateral lobes erect, sub-orbicular, $2.0-2.5 \times 0.7-1.0 \mathrm{~cm}$, fimbriate or erose-lacerate on margin, adaxially with reddish brown longitudinal stripe; median lobe ovate-triangular or triangular-lanceolate, $1.8-2.5 \times 1.0-1.2 \mathrm{~cm}$, acute to apiculate, margin fimbriate or erose-lacerate; two low lateral keels, extending from lip base to base of median lobe, margin fimbriate or erose-lacerate; column arcuate, $2.0-2.5 \times 0.4-0.6 \mathrm{~cm}$ long, yellow at front below apex, both sides winged, wings gradually broadening from the middle to the apex, apex margin white, irregularly toothed; anther cap elliptic triangular, adaxially light pale yellow-green, abaxially white, margin membranous at base, apex obtuse; pollinia two; rostellum ligulate-triangular.

Phenology. Flowering from April to May and fruiting from June to July.

Etymology. The species epithet refers to its large attractive flowers.

Distribution and habitat. Coelogyne magnifica is currently known only from the type locality of Putao, Kachin State, northern Myanmar. It is a predominantly epi- 


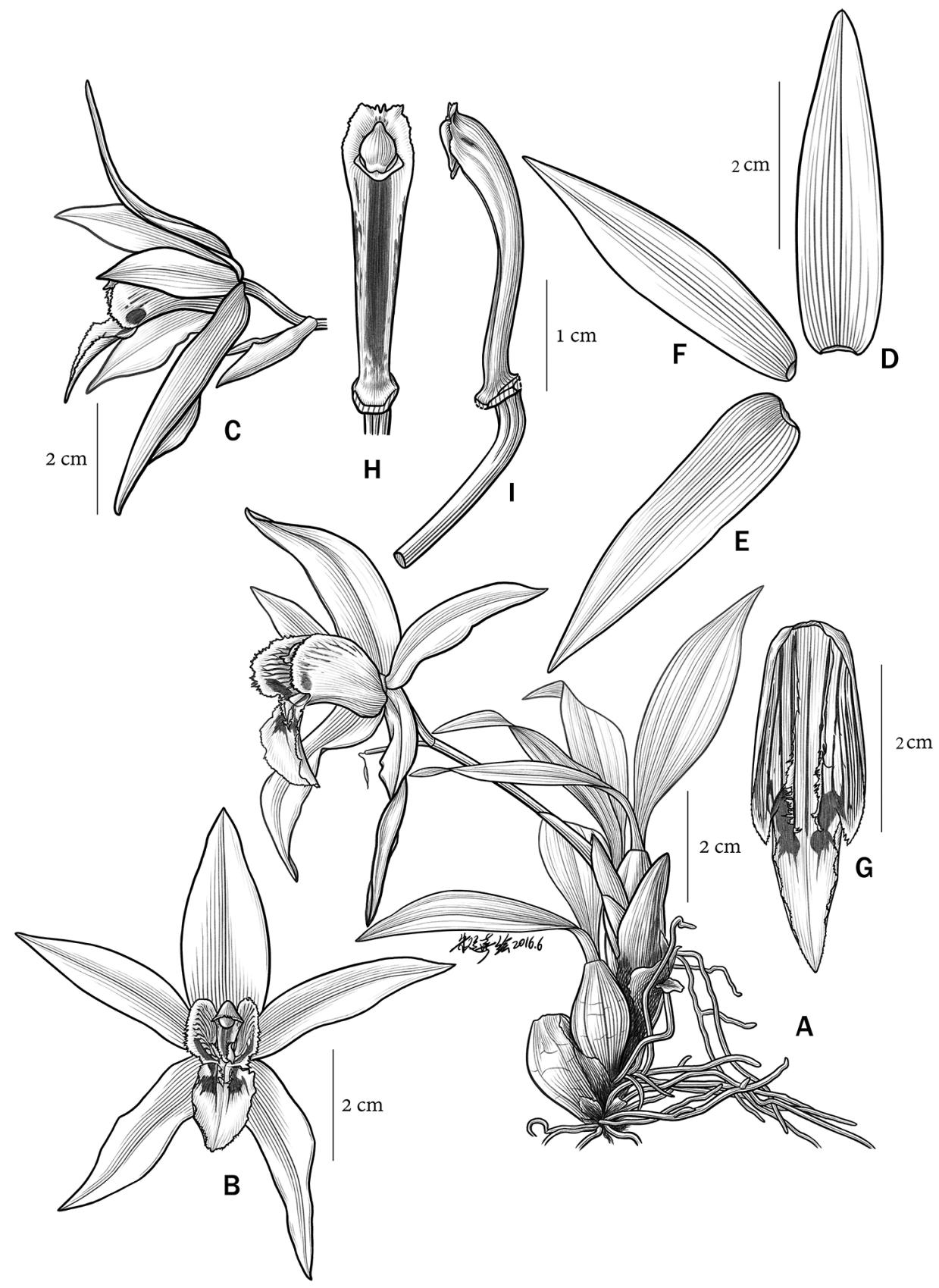

Figure I. Coelogyne magnifica Y.H. Tan, S.S. Zhou \& B. Yang sp. nov. A Habit B Flower (front view) C Flower (side view) D Dorsal sepal E Lateral sepal F Petal G Lip H Column (frontal view) I Column (lateral view). Illustration by Yunxi Zhu. 

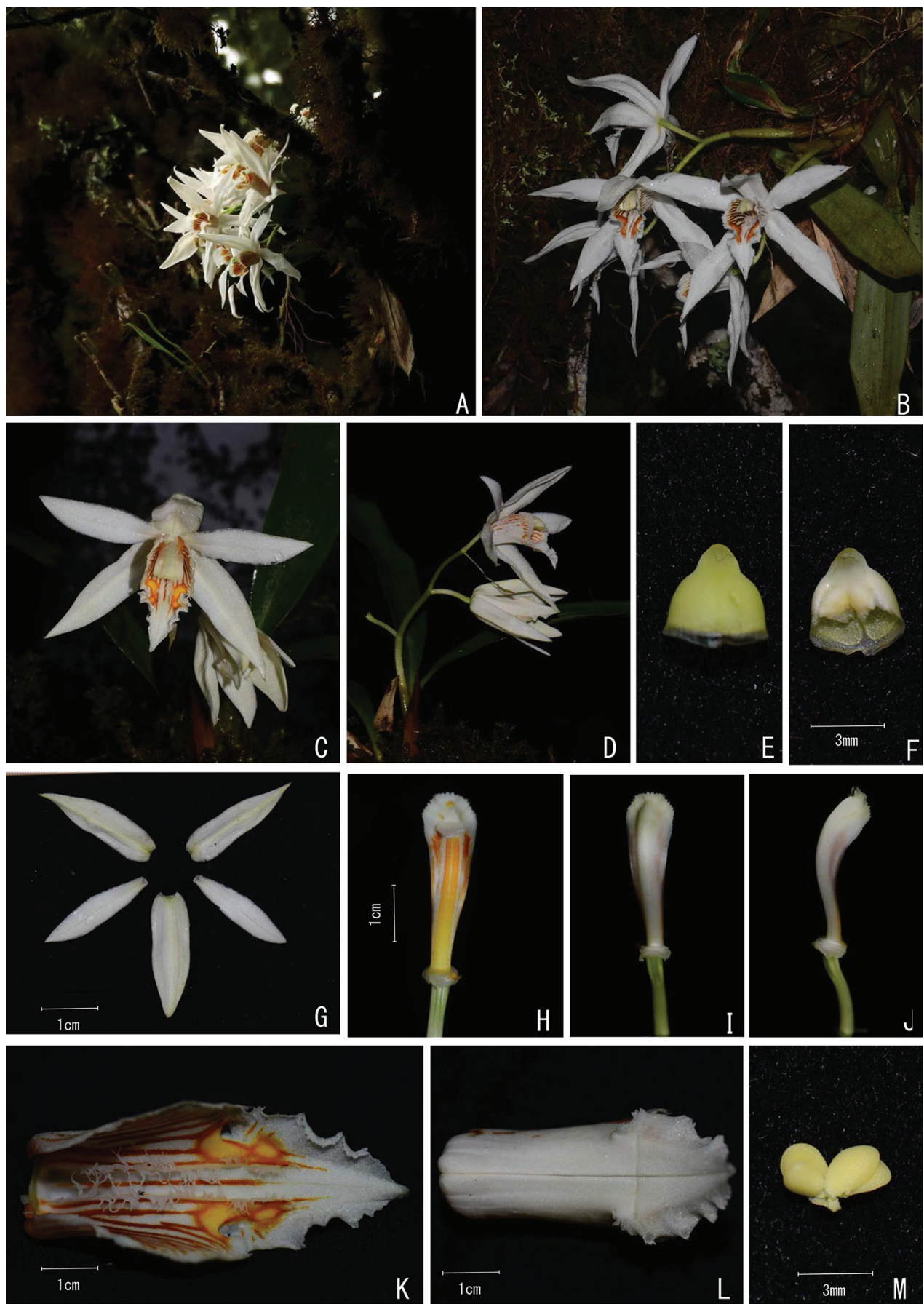

Figure 2. Coelogyne magnifica Y.H. Tan, S.S. Zhou \& B. Yang sp. nov. A-D Habit E Anther cap (abaxial view) F Anther cap (adaxial view) G Tepals H Column (adaxial view) I Column (abaxial view) J Column (lateral view) K Lip (adaxial view, showing the two lateral keels and two patches) L Lip (abaxial view) M Pollinia. Photographed by Y.H. Tan, Q. Liu \& X.L. Zeng. 
phytic species that grows on moss-covered branches and tree trunks and sometimes also on rocks, in humid montane forests, at an elevation 2400-2500 m a.s.l.

Conservation status. The type locality of this new species is within the Hponkanrazi Wildlife Sanctuary, which is an officially protected area under the management of the Myanmar Forest Department. During field investigations in 2016 and 2017, three populations were found in the reserve area, each of which consisted of ca. 100 individuals. As found, inhabitants are well protected and almost undamaged and flowering individuals are not vulnerable to human interference or picking. Based on current information and according to IUCN Red List category (IUCN 2012), Coelogyne magnifica is assigned a preliminary status of Least Concern (LC).

Additional specimens examined (paratypes). Myanmar. Kachin State: Putao, Hponkanrazi Wildlife Sanctuary, 9753'10.48"E, 2741'17.60"N, alt. 2400 m, 4 May 2016, Myanmar Exped. 0100 (HITBC). Ibid., alt. 2450 m, 7 May 2016, Myanmar Exped. 0188 (HITBC).

Key to the species of Coelogyne sect. Ocellatae, adapted from Li and Dao (2014)

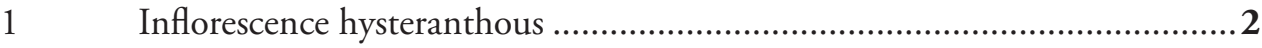

- Inflorescence proteranthous or synanthous ...................................... 3

2 Lowermost bract of rachis with flower ........................... C. bysterantha

- Lowermost bract of rachis sterile .........................................

3 Pseudobulb obovoid, born distantly, 1.3-5.0 cm apart ............. C. occultata

- $\quad$ Pseudobulb ellipsoid, born clustered, less than $1.3 \mathrm{~cm}$ apart .....................4

$4 \quad$ Keels on lip plate-like shaped ....................................... C. platylamellata

Keels on lip clavate or rod-shaped ..................................................5

$5 \quad$ Keels starting $0.3 \mathrm{~cm}$ away from the base of the hypochile. C. gongshanensis

- Keels starting right from the base of the hypochile ................................6

6 Lateral lobes of lip length $3-3.2 \mathrm{~cm}$ when flattened ................... C. wardii

- $\quad$ Lateral lobes of lip length $1-2.5 \mathrm{~cm}$ when flattened ............................. 7

$7 \quad$ Margin of lateral lobes of lip crenulate or crispate ...............................8

- $\quad$ Margin of lateral lobes of lip erose or denticulate ....................................9

8 Flowers almost solid yellowish brown, lip with a large, bright yellow patch...

- Flowers creamy-yellow, lip with four dark red patches

$9 \quad$ Lateral keels of lip clavate and with erose lacerate or crenulate margins $\mathbf{1 0}$

- Lateral keels of lip rod-shaped and with entire margins..........................11

10 Sepals and petals more than $4.0 \mathrm{~cm}$ long.............................. C. magnifica

Sepals and petals less than $3.5 \mathrm{~cm}$ long ............................................ 12

11 Flowers 4-8, mid-lobe acute at apex ...................................... . nitida

Flowers 2-3, mid-lobe cuspidate at apex.................................... C. ttyuii

12 Yellow eyelike blotches surrounded by reddish orange on lip.........C. corymbosa

Dark brown eyelike blotches surrounded by brownish-yellow on lip 


\section{Discussion}

According to monographic works (Clayton 2002, Chen and Clayton 2009, George and George 2011, Subedi 2011), Coelogyne magnifica obviously belongs to sect. Ocellatae Pfitzer \& Kraenzl. (Pfitzer and Kraenzlin 1907), which is characterised by the white or pale coloured flowers with colourful eyelike blotches on the lateral lobes and lip. This section shows its centre of diversity in the Himalayas (Subedi 2011). Coelogyne magnifica is similar to both $C$. corymbosa and $C$. taronensis in terms of vegetative morphology and shape of the flowers, but differs mainly with respect to the characters of patches and keels on the lip. Morphologically, the new species is most similar to C. corymbosa, with both having white flowers, ovoid pseudobulbs sometimes and obovateoblong leaf blades. These two species are also distributed in the same locality in north Myanmar. Nevertheless, the new species differs from C. corymbosa in having slightly smaller pseudobulbs, shorter leaf blades, a greater number of larger flowers, two bright yellow patches surrounded by shiny brownish red (vs. four yellow eye-like blotches) and two fimbriate or erose-lacerate lateral keels on the lip (vs. two-three keels, with margins wavy or crenulate) (Table 1). The tepals (perianth lobes, including sepals, petals and lip) of C. magnifica are lanceolate, $4.0-4.9 \mathrm{~cm}$ long (vs. mostly elliptic to ovate,

Table I. Morphological comparison of Coelogyne magnifica and its closely related species.

\begin{tabular}{|c|c|c|c|}
\hline Characters & Coelogyne magnifica & Coelogyne corymbosa & Coelogeny taronensis \\
\hline Pseudobulbs & $\begin{array}{l}\text { ovoid or oblong-ovoid, } \\
2-2.5 \times 1-1.3 \mathrm{~cm}\end{array}$ & $\begin{array}{c}\text { oblong-ellipsoid to ovoid, } \\
2-6 \times 1.1-2.5 \mathrm{~cm}\end{array}$ & $\begin{array}{c}\text { ovoid, } 2-2.5 \times 1.3- \\
1.8 \mathrm{~cm}\end{array}$ \\
\hline Leaf blade & $\begin{array}{c}\text { obovate-oblong or narrowly } \\
\text { ovate, } 4-6 \times 0.8-1.4 \mathrm{~cm}, \\
5-7 \text { veined }\end{array}$ & $\begin{array}{l}\text { oblong-oblanceolate to } \\
\text { obovate-oblong, } 4.5-15 \times \\
1-3 \mathrm{~cm}\end{array}$ & $\begin{array}{c}\text { elliptic or obovate, } \\
9.8-13.5 \times 2.2-2.3 \\
\mathrm{~cm}\end{array}$ \\
\hline Pedicel and ovary & $1.3-1.6 \mathrm{~cm}$ & $2.5-3.1 \mathrm{~cm}$ & $2.9-3.2 \mathrm{~cm}$ \\
\hline Flowers & white & white & creamy-yellow \\
\hline Dorsal sepal & $\begin{array}{c}\text { lanceolate, } \\
4.0-6.0 \times 1.0-1.3 \mathrm{~cm}\end{array}$ & $\begin{array}{l}\text { elliptic to narrowly ovate, } \\
2.6-3.5 \times 0.8-1.3 \mathrm{~cm}\end{array}$ & $\begin{array}{c}\text { elliptic to narrowly } \\
\text { ovate, } 3-3.5 \times 1.3-1.7 \\
\mathrm{~cm}\end{array}$ \\
\hline Lateral sepals & $\begin{array}{c}\text { lanceolate, } \\
5.0-5.5 \times 0.9-1.5 \mathrm{~cm}\end{array}$ & $\begin{array}{l}\text { oblong-elliptic or narrowly } \\
\text { ovate, } 2.6-3.7 \times 0.7-2.1 \mathrm{~cm}\end{array}$ & $\begin{array}{c}\text { oblong-elliptic or } \\
\text { narrowly ovate, } 3.2- \\
3.5 \times 0.8-1.2 \mathrm{~cm}\end{array}$ \\
\hline Petals & $\begin{array}{c}\text { lanceolate, } \\
4.0-5.3 \times 0.6-1.0 \mathrm{~cm}\end{array}$ & $\begin{array}{c}\text { narrowly elliptic or narrowly } \\
\text { obovate, } 2.4-3.2 \times 0.6- \\
1.2 \mathrm{~cm}\end{array}$ & $\begin{array}{l}\text { elliptic-oblong, } 2.8- \\
3.5 \times 0.6-0.8 \mathrm{~cm}\end{array}$ \\
\hline Lip & $\begin{array}{c}\text { narrowly ovate, } \\
3.8-4.9 \times 1.7-2.2 \mathrm{~cm} \\
\end{array}$ & $\begin{array}{c}\text { ovate or elliptic, } 2.1-3.3 \times \\
1.4-2.1 \mathrm{~cm} \\
\end{array}$ & $\begin{array}{c}\text { ovate, } 2.8-3.9 \times \\
2.1-2.6 \mathrm{~cm} \\
\end{array}$ \\
\hline $\begin{array}{l}\text { Patches or } \\
\text { blotches }\end{array}$ & $\begin{array}{c}\text { two bright yellow patches } \\
\text { surrounded by shiny } \\
\text { brownish red }\end{array}$ & $\begin{array}{l}\text { four yellow blotches } \\
\text { surrounded by reddish orange }\end{array}$ & four dark red patches \\
\hline Keels & 2 fimbriate or erose lacerate & 2-3 wavy, entire or crenulate & $\begin{array}{l}3 \text { crenulate to wavy } \\
\text { and slightly papillose }\end{array}$ \\
\hline
\end{tabular}


2.4-3.7 cm long in C. corymbosa). Although the other morphologically similar species, C. taronensis, is similar to the new species with respect to ovoid pseudobulbs and in flower size, the new species differs from $C$. taronensis with regards to its white flowers (vs. creamy yellow in C. taronensis) (Figure 2), smaller leaf blades (Table 1), patches (two bright yellow patches vs. four dark red patches) and keels (two keels vs. three keels) on the lip. The major differences between the species are outlined in Table 1.

\section{Acknowledgements}

The authors are grateful to Xiaohua Jin and another two anonymous reviewers and editors for their positive and constructive comments and suggestions for this manuscript. We are also grateful to the Forest Research Institute of Myanmar for permission to conduct this study in northern Myanmar and for their support and collaboration. We are grateful to Myint Zaw and Myint Kyaw for their exhaustive help in the field work. We thank Yunxi Zhu for the illustration and Xiangle Zeng for providing us a photo. This work was financially supported by a project of the Southeast Asia Biodiversity Research Institute, Chinese Academy of Sciences (Grant No.Y4ZK111B01).

\section{References}

Aung YL, Jin XH, Schuiteman A (2017) Coelogyne putaoensis (Orchidaceae), a new species from Myanmar. PhytoKeys 82: 27-34. https://doi.org/10.3897/phytokeys.82.13172

Chen XQ, Clayton D (2009) Coelogyne. In: Wu ZY, Raven PH, Hong DY (Eds) Flora of China,

Vol 25. Science Press, Beijing and Missouri Botanical Garden Press, St. Louis, 315-325.

Clayton D (2002) The genus Coelogyne: a synopsis. Natural History Publications, Kota Kinabalu, $316 \mathrm{pp}$.

George É, George JC (2011) Les Coelogynes. Belin, Paris, 607 pp.

Gogoi K, Das R, Yonzone R (2015) Orchids of Assam, North East India - An annotated checklist. International Journal of Pharmacy \& Life Sciences 6: 4123-4156.

Gravendeel B (2000) Reorganising the orchid genus Coelogyne a phylogenetic classification based on morphology and molecules. National Herbarium Nederland, Universiteit Leiden branch, Leiden, 1-208.

Gravendeel B (2005) Coelogyne. In: Pridgeon AM, Cribb PJ, Chase MW, Rasmussen FN (Eds) Genera Orchidacearum, Volume 4. Epidendroideae (Part one). Oxford University Press, Oxford, 44-51.

Gravendeel B, Chase MW, De Vogel EF, Roos MC, Ted HM Mes, Bachmann K (2001) Molecular phylogeny of Coelogyne (Epidendroideae; Orchidaceae) based on plastid RFLPS, mat $K$ and nuclear ribosomal ITS sequences: evidence for polyphyly. American Journal of Botany 88: 1915-1927. https://doi.org/10.2307/3558367

Gravendeel B, de Vogel EF (1999) Revision of Coelogyne section Speciosae (Orchidaceae). Blumea 44: 253-320. 
Hooker JD (1890) Orchideae. In: Hooker JD (Ed.) Flora of British India. Vol 6. L. Reeve \& Co., London, 193-194.

IUCN (2012) IUCN Red List Categories and Criteria, Version 3.1. 2nd Eds., IUCN, Gland.

Kress J, Robert A, DeFilippes E, Kyi YY (2003) A checklist of the trees, shrubs, herbs and climbers of Myanmar. Contributions from the United States National Herbarium 45: 1-590.

Kurzweil H, Lwin S (2013) A guide to orchids of Myanmar. Natural History Publications (Borneo) Sdn. Bhd., Kota Kinabalu, 196 pp.

Li R, Dao ZL (2014) A new species of Coelogyne (Orchidaceae) from western Yunnan, China. Phytotaxa 162: 115-119. http://dx.doi.org/10.11646/phytotaxa.162.2.7

Lindley J (1821) Collectanea Botanica. Richard \& Arthur Taylor, London, 1-41.

Pelser PB, Gravendeel B, de Vogel EF (2000) Revision of Coelogyne section Fuliginosae (Orchidaceae). Blumea 45: 253-273.

Pfitzer E, Kraenzlin F (1907) Coelogyne. In: Engler HGA (Ed.) Das Pflanzenreich, Heft 32. Akademie Verlag, Berlin, 20-82.

Sierra SEC, Gravendeel B, de Vogel EF (2000) Revision of Coelogyne section Verrucosae (Orchidaceae): A new sectional delimitation based on morphological and molecular evidence. Blumea 45: 275-318.

Subedi A (2011) New species, pollinator interactions and pharmaceutical potential of Himalayan orchids. Dissertation, Leiden University, Leiden, 13-58.

Yonzone R, Lama D, Bhujel RB, Rai S (2012a) Orchid species diversity of Darjeeling Himalaya of India. International Journal of Pharmacy \& Life Sciences 3: 1533-1550.

Yonzone R, Lama D, Bhujel RB, Rai S (2012b) Studies on the genetic diversity, distribution and diversity of Coelogyne Lindl. Orchidaceae of Darjeeling Himalaya of West Bengal, India. International Journal of Pharma and Bio Sciences 2: 506-512. 